Article

\title{
Agribusiness as an Attractive Place to Work- A Gender Perspective
}

\author{
Magdalena Kozera-Kowalska ${ }^{1}$ and Jarosław Uglis ${ }^{2, *(D)}$ \\ 1 Department of Law and Enterprise Management in Agribusiness, Poznań University of Life Sciences, \\ 28 Wojska Polskiego, 60-637 Poznań, Poland; magdalena.kozera@up.poznan.pl \\ 2 Laboratory of Rural Tourism, Poznań University of Life Sciences, 28 Wojska Polskiego, 60-637 Poznań, Poland \\ * Correspondence: jaroslaw.uglis@up.poznan.pl
}

Citation: Kozera-Kowalska, M.;

Uglis, J. Agribusiness as an Attractive Place to Work-A Gender

Perspective. Agriculture 2021, 11, 202.

https://doi.org/10.3390/

agriculture 11030202

Academic Editor: Piotr Prus

Received: 5 February 2021

Accepted: 25 February 2021

Published: 1 March 2021

Publisher's Note: MDPI stays neutral with regard to jurisdictional claims in published maps and institutional affiliations.

Copyright: (c) 2021 by the authors. Licensee MDPI, Basel, Switzerland. This article is an open access article distributed under the terms and conditions of the Creative Commons Attribution (CC BY) license (https:// creativecommons.org/licenses/by/ $4.0 /)$.
Abstract: Agribusiness is both a complex social process and a market structure, consisting of many independent economic entities that generate demand for labour in the sector. The role of people whose activity is directly or indirectly related to the production of food products, the acquisition of resources, and the processing and production of ready food was considered. The way gender affects people's decision to work in this sector and university graduates' perception of agribusiness being an ideal job were also analysed. A total of 485 students, from four fields of study, from the Poznań University of Life Sciences were surveyed between 2016 and 2019. In the case of undergraduate students, it was determined that while they perceive that working in agribusiness is an interesting career stage, they are also convinced that they could easily find a job outside of this sector. Additionally, from a gender perspective, men and women view working in agribusiness differently. Women see it as an opportunity for self-development and building good social relations as well as acting for the benefit of the environment. For men, job-related prestige and economic benefits are much more important. Men were found to have higher aspirations for pursuing their own businesses, whereas women were more likely to pursue further education. The attitudes towards working in agribusiness represented by the respondents are a good predictor of meeting its knowledge needs.

Keywords: agribusiness; agriculture; gender perspective of work; ideal job; Generation Z view of work

\section{Introduction}

Agribusiness is a complex and diverse sub-system of the national economy, which includes entities handling production, processing and distribution of food and its derivatives as well as other related services. It integrates independent, economically-separate entities that work together to jointly make the national food economy more competitive [1]. At the same time, agribusiness is a complex social process involving people whose activities are directly or indirectly related to the production of food products, obtaining and processing resources, and the production of ready food. From a yet another perspective, agribusiness is a complex structure consisting of many independent labour-demand-generating economic entities, whose activities are intertwined and complementary [2-4]. Such entities employ nearly 44 million Europeans, half of whom work in agriculture itself [5]. Providing both resources for processing for ready food products for direct consumption, agriculture is one of the leading components of this system. Due to the continuing efforts to adapt this sector to the requirements of sustainable development, there is an increasing demand for knowledge in it, both in regard to technologies and skilled workers [6-8]. However, by no means does this indicate that the demand for labour in this sector can be easily met. Despite the well-developed specialised agriculture and agribusiness education at the secondary and tertiary education system levels, relatively few people are interested in working in this sector [4]. This is related to such things as the well-established stereotype 
of agriculture and its related sectors being hard and poorly-paid work, which does not offer prospects for rapid social advancement and prestige $[9,10]$.

The paper aims to identify the characteristics of an ideal job, as perceived by young people who will enter the agribusiness job market upon completing their academic education. Additionally, the analysis was performed from a gender perspective to attempt to determine the extent to which graduates of different genders are interested in entering the food economy market (including taking up one of the occupations listed in the study). According to a literature analysis [11-15], the following research hypotheses were adopted in the study:

1. H1 -both men and women perceive working in agribusiness as something close to an ideal job.

2. H2-women's expectations concerning the demands of this type of work and its environmental impact are higher than men's.

3. H3 - women are less likely than men to decide to set up their own business.

4. H4-since the examined group of graduates belongs to the so-called Generation Z, this affects what they perceive as an ideal job.

This study is our contribution to the debate on the role of gender in agricultural and agribusiness development. Another reason for researching this area was the increasing feminisation of faculties at agricultural, vocational and agricultural technology universities, which aim to educate specialised employees to support the needs of broadly-defined agribusiness, not only in Poland but also in other European countries [16-19]. An additional premise of our research is the fact that in recent years there has been a steady and regular decline in the number of university graduates in Poland (from over 1.9 million in the academic year 2008/2009 to 1.2 million in the academic year 2018/2019), i.e., people who would feed the knowledge transfer stream for agribusiness. At the same time, there is an increase in the feminisation of all fields of study, including agriculture, and the share of women among the total number of students is as high as $58.0 \%$ (in full-time studies, this number is much higher and amounts to just over 65\%) [20].

\section{Rural Areas as Places of Employment--Theoretical Background}

On the one hand, rural areas are natural locations for agribusiness enterprises while on the other, they are ideal places to live, work and do business [21-23]. This is confirmed by research on young people graduating in agriculture, agricultural technology, and certain economics majors related to the food economy [23]. These educational fields provide students with a wide range of competencies, which enables them to undertake various types of work in widely-understood agribusiness. In Poland, this sector employs more than $20 \%$ of the total workforce and generates $6.6 \%$ of the gross value added [24]. Due to its complexity, it generates employment not only in food production, processing, distribution and consumption areas but also in clothing production as well as storage and shelter space solutions [1]. The segments that are considered primary for agribusiness include agriculture (construed as the production of food resources and finished food) and the related purchasing of agricultural resources and the associated storage, transportation, and agricultural inputs industries, the food industry, fishing and forestry industries, wholesale and retail food trade, and the services related to the functioning of this entire system [25]. Each of the identified elements (subsectors) generates a separate demand for labour, which differs both in terms of employee quality (including skills) and numbers (Figure 1). These characteristics change over time and depend on such factors as the economic processes occurring in the economies of specific countries and other elements. 


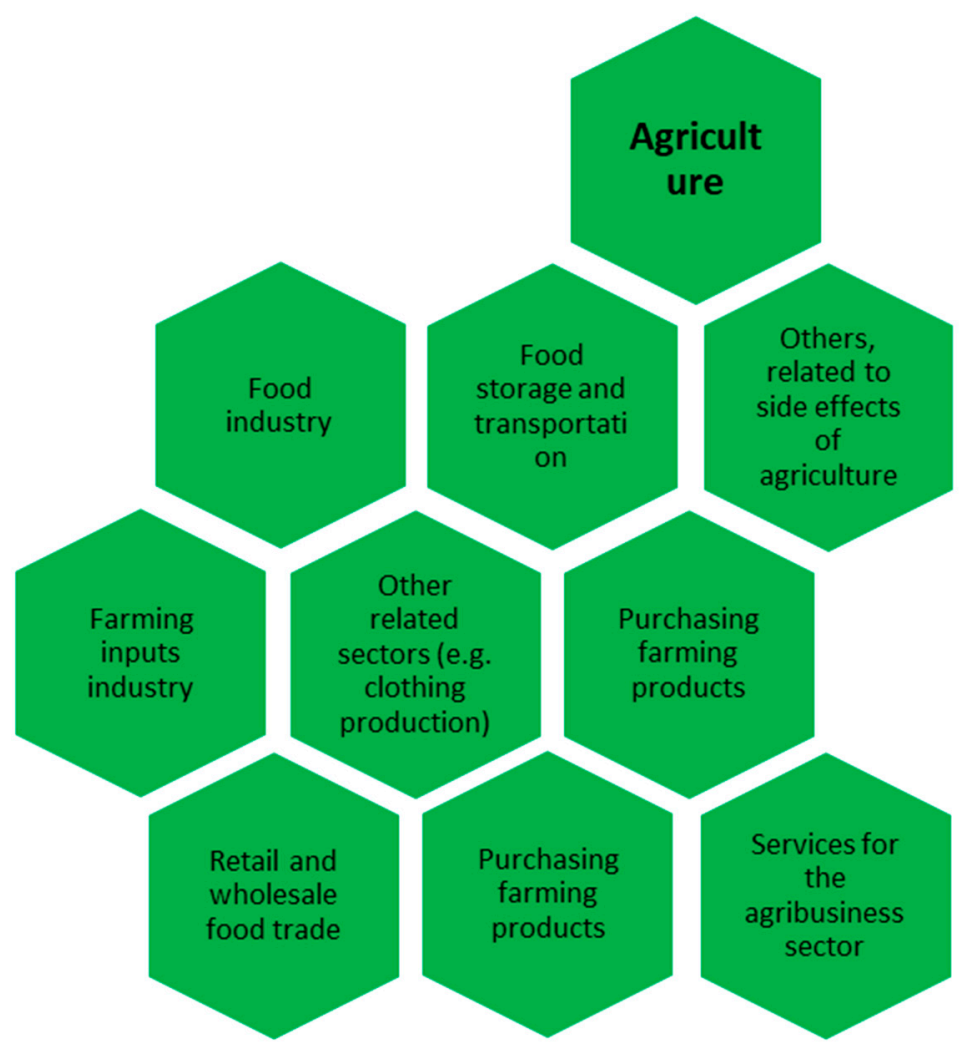

Figure 1. Areas generating labour demand in agribusiness. Source: own study.

For example, in Poland, employment in specific agribusiness areas has changed over the years, in terms of structure and quality alike. This is especially true for agriculture, which had been a sector characterised by employment redundancy for many years [26-28]. The factor that triggered the transformation in this regard was the increase in demand for labour in other sectors of the economy as well as the higher and relatively stable wages (the so-called wage premium) in non-agricultural sectors $[29,30]$. Current issues that contribute to the abandonment of agriculture include the specific natural and social conditions related to its typically low productivity, which affects the level of generated income, and as a result, salaries [31]. In the case of Poland, the significant farm fragmentation and a high share of farms with low marketable agricultural output yield are also not without significance. The progressing consolidation processes further accelerate changes in this area while also releasing the surplus labour force from the sector, which should be gradually replaced by fewer numbers of highly-skilled young people (graduates of university courses dedicated to agribusiness). Nonetheless, the pace of personnel replacement can hardly be deemed sufficient, due to such factors as disincentivising income levels that still affect many agribusiness subsectors, especially agriculture. This discourages young people from entering the sector, effectively limiting the rate of qualitative employment changes [32,33]. Yet, the simultaneous expansion of commodity agriculture causes an increase in both the demand for knowledge transfer to agriculture and the degree of knowledge absorption. The stream of the workforce leaving agriculture is directed towards the food industry, agricultural input and service industries, and other agribusiness sectors. This natural reallocation of labour resources from lower-productivity sectors (such as agriculture) to higher-productivity ones is often limited by skill mismatch and low education levels.

Today, there is no denying the fact that due to the ever more intense balancing processes, agribusiness is becoming a sector with an increasing demand for knowledge. However, both the need for knowledge and the degree of its absorption vary widely within the sector. Manufacturing is typically regarded as the leader in this regard, with agriculture being deemed the outsider. In the case of the latter, researchers primarily point to the 
farmers' low levels of education, limited professional skills, and broadly-defined reluctance to pursue lifelong learning [34-36]. From this point of view, the increasing role of women as both farm and food supply chain entity managers was emphasized as well, with this factor having an increasing influence on the implementation of pro-ecological goals and challenges vital for modern agribusiness (e.g., reducing the sector's impact on climate change, seeking to preserve the rural landscape, developing non-agricultural activities, etc.), thanks to increased knowledge and striving for continuous improvement [37,38]. With the imminent implementation of the European Green Deal strategy, the role of women in this regard becomes even more vital, as it is primarily women who attach more importance to combining their own development and business activity with pro-social and pro-environmental actions [39-42]. Considering the upcoming changes-especially those related to the implementation of the European Green Deal strategy-in this paper, the authors decided to examine the attractiveness of employment in the agribusiness sector from a gender perspective.

\section{Materials and Methods}

The subject of the empirical study was the result of surveys conducted annually between 2016 and 2019 among students of the Poznań University of Life Sciences before their diploma exam at the end of their undergraduate course. The survey covered students of four fields of study, i.e., animal science, economics, finance and accounting, and social policy. The data was collected by using a questionnaire technique with an offline mode. The study was voluntary, anonymous and non-exhaustive. The average survey response rate was higher, over $71 \%$. The sample collected during the study period was 485 surveys, with participants being predominantly female $(81.4 \%)$. It should be noted that the research sample's gender structure reflects that of the general Poznań University of Life Sciences student population, which confirms the strong feminisation the university's courses.

Most respondents were between 21 and 23 years of age and had not yet taken their diploma exam (final engineering or undergraduate exam). Information provided by students throughout the study included that related to basic research aspects, sociodemographic characteristics, work experience and plans to start a business after graduation.

The research used an auditorium survey questionnaire (Supplementary Materials), which ensures responder anonymity, enables measurement control, and is characterised by a relatively high survey response rate [4]. The survey instrument was prepared by adapting the questionnaire used by Bednarska [43], with its primary part including questions about the characteristics of an ideal job that is possible to find after finishing the undergraduate course, and the other part concerning the attractiveness of working in agribusiness and the students' plans to start their own business after graduation. A total of 29 characteristics of an ideal job and 5 questions about working in agribusiness were assessed. The evaluation was performed using a seven-point Likert scale (1-definitely not, 4-no opinion, 7-definitely yes), the use of which made it possible to increase the difference measurement sensitivity in the evaluation of the characteristics examined.

The main part of the survey instrument consisted of questions about the characteristics of a potential workplace that determine whether it is an ideal job. Five job dimensions were examined, i.e., job contents (10 features), economic benefits (4 features), career opportunities (5 features), social relations ( 5 features), and reputation (4 features). Table 1 shows the criteria for each area. 
Table 1. Areas of research interest and associated features.

\begin{tabular}{|c|c|}
\hline Area & Area Features \\
\hline Job contents & $\begin{array}{ll}- & \text { work matching your interests } \\
- & \text { challenging work } \\
- & \text { allows you to make full use of all your skills and knowledge } \\
- & \text { ensures high variability of tasks performed } \\
- & \text { allows you to decide for yourself how to perform your duties } \\
- & \text { involves a high volume and rapid pace of work } \\
- & \text { involves irregular working hours } \\
- & \text { requires mobility } \\
- & \text { ease of commuting } \\
- & \text { involves working in an attractive location }\end{array}$ \\
\hline $\begin{array}{l}\text { Economic } \\
\text { benefits }\end{array}$ & $\begin{array}{ll}\text { - } & \text { guarantees a high remuneration } \\
\text { - } & \text { offers extensive social and living benefits } \\
\text { - } & \text { provides you with modern equipment needed to perform your } \\
\text { duties } & \\
\text { - } & \text { offers stable employment conditions }\end{array}$ \\
\hline $\begin{array}{c}\text { Career } \\
\text { opportunities }\end{array}$ & $\begin{array}{l}\text { - } \quad \begin{array}{l}\text { enables you to influence decisions vital to the company } \\
\text { - }\end{array} \text { provides a clear career/promotion path } \\
\text { - } \quad \text { enables you to improve your skills } \\
\text { - } \quad \begin{array}{l}\text { provides the opportunity for long-term professional } \\
\text { development within the company }\end{array} \\
\text { - } \quad \text { guarantees acquiring skills that may prove useful in other } \\
\text { workplaces }\end{array}$ \\
\hline Social relations & $\begin{array}{ll}\text { - } & \text { allows you to seamlessly balance your private and professional } \\
\text { - } & \text { life } \\
\text { - } & \text { friendly workplace atmosphere } \\
\text { ensures that you are treated with respect by clients and } \\
\text { - } \quad \text { maklleagues alike } \\
\text { - } \quad \text { performed feel supported by colleagues } \\
\text { - } \quad \text { provides a sense of belonging and integration with the team }\end{array}$ \\
\hline Reputation & $\begin{array}{ll}\text { - } & \text { related to providing high-quality products/services } \\
\text { - } & \text { characterised by high social prestige } \\
\text { - } & \text { gives you a sense of pride in your duties } \\
\text { - } & \text { working at a company that supports the local community }\end{array}$ \\
\hline
\end{tabular}

Source: own study.

The second part included questions on the respondents' opinions on the attractiveness of working in agribusiness and their willingness to work as a sales representative in this sector (the profession for the study was selected based on an analysis of the number of offers addressed to students, published by the PULS Career Office). A seven-point Likert scale was used in this case as well. The final issue addressed was an assessment of the possibility of finding employment outside of agribusiness on similar or better terms.

All material gathered was subjected to preliminary analysis, followed by statistical analysis, with the identification of significant differences in the perception of the examined variables made possible by the chi-square independence test, the Mann-Whitney $U$ test and the Wald-Wolfowitz runs test. The statistical analysis was performed using the STATISTICA 13.3 program (TIBCO Software Inc., Palo Alto, USA). Three data presentation methods were used to characterise the phenomena examined: tabular, graphical and descriptive. 


\section{Results}

\subsection{Varying Expectations Concerning an Ideal Job}

When examining the students' expectations about their ideal workplace, all of the characteristics included in the survey questionnaire were assumed to have a significant impact on their perception of a workplace. However, a detailed analysis of the results revealed a significant variation in the scores given to each factor, as confirmed by the variation coefficient calculated for them (Table 2).

Table 2. Perceptions regarding the image of an ideal job.

\begin{tabular}{|c|c|c|c|c|c|}
\hline No. & Tested Feature & Average & $\begin{array}{c}\text { Standard } \\
\text { Deviation }\end{array}$ & Skewness & Kurtosis \\
\hline 1 & work matching your interests & 6.40 & 1.05 & -2.42 & 7.10 \\
\hline 2 & challenging work & 5.31 & 1.38 & -1.05 & 1.25 \\
\hline 3 & $\begin{array}{l}\text { allows you to make full use of all your } \\
\text { skills and knowledge }\end{array}$ & 6.10 & 1.10 & -1.43 & 2.17 \\
\hline 4 & $\begin{array}{l}\text { ensures high variability of tasks } \\
\text { performed }\end{array}$ & 5.81 & 1.28 & -1.19 & 1.26 \\
\hline 5 & $\begin{array}{l}\text { allows you to decide for yourself how } \\
\text { to perform your duties }\end{array}$ & 5.73 & 1.30 & -0.94 & 0.38 \\
\hline 6 & $\begin{array}{l}\text { involves a high volume and rapid } \\
\text { pace of work }\end{array}$ & 4.45 & 1.58 & -0.40 & -0.38 \\
\hline 7 & involves irregular working hours & 3.05 & 2.10 & 0.62 & -0.98 \\
\hline 8 & requires mobility & 3.71 & 1.92 & 0.14 & -1.09 \\
\hline 9 & ease of commuting & 5.92 & 1.39 & -1.41 & 1.59 \\
\hline 10 & $\begin{array}{l}\text { involves working in an attractive } \\
\text { location }\end{array}$ & 5.36 & 1.58 & -0.80 & -0.04 \\
\hline 11 & guarantees a high remuneration & 6.37 & 1.01 & -1.75 & 3.01 \\
\hline 12 & $\begin{array}{l}\text { offers extensive social and living } \\
\text { benefits }\end{array}$ & 5.67 & 1.47 & -1.12 & 0.98 \\
\hline 13 & $\begin{array}{l}\text { provides you with modern equipment } \\
\text { needed to perform your duties }\end{array}$ & 5.98 & 1.14 & -1.06 & 0.95 \\
\hline 14 & offers stable employment conditions & 6.38 & 1.02 & -1.95 & 3.69 \\
\hline 15 & $\begin{array}{l}\text { enables you to influence decisions } \\
\text { vital to the company }\end{array}$ & 5.40 & 1.29 & -0.53 & 0.04 \\
\hline 16 & $\begin{array}{l}\text { provides a clear career/promotion } \\
\text { path }\end{array}$ & 5.97 & 1.19 & -1.34 & 2.16 \\
\hline 17 & enables you to improve your skills & 6.24 & 1.05 & -1.84 & 4.47 \\
\hline 18 & $\begin{array}{l}\text { provides the opportunity for } \\
\text { long-term professional development } \\
\text { within the company }\end{array}$ & 5.94 & 1.18 & -1.20 & 1.42 \\
\hline 19 & $\begin{array}{l}\text { guarantees acquiring skills that may } \\
\text { prove useful in other workplaces }\end{array}$ & 5.86 & 1.25 & -1.13 & 1.11 \\
\hline 20 & $\begin{array}{l}\text { allows you to seamlessly balance your } \\
\text { private and professional life }\end{array}$ & 6.08 & 1.34 & -1.66 & 2.51 \\
\hline 21 & friendly workplace atmosphere & 6.33 & 1.02 & -1.67 & 2.57 \\
\hline 22 & $\begin{array}{l}\text { ensures that you are treated with } \\
\text { respect by clients and colleagues alike }\end{array}$ & 6.28 & 1.05 & -1.72 & 3.45 \\
\hline 23 & $\begin{array}{l}\text { makes you feel supported by } \\
\text { colleagues }\end{array}$ & 6.06 & 1.18 & -1.58 & 2.92 \\
\hline 24 & $\begin{array}{l}\text { performed while working with } \\
\text { competent colleagues }\end{array}$ & 6.05 & 1.15 & -1.44 & 2.29 \\
\hline
\end{tabular}


Table 2. Cont.

\begin{tabular}{clcccc}
\hline No. & \multicolumn{1}{c}{ Tested Feature } & Average & $\begin{array}{c}\text { Standard } \\
\text { Deviation }\end{array}$ & Skewness & Kurtosis \\
\hline 25 & $\begin{array}{l}\text { provides a sense of belonging and } \\
\text { integration with the team }\end{array}$ & 5.89 & 1.22 & -1.31 & 2.06 \\
\hline 26 & $\begin{array}{l}\text { related to providing high-quality } \\
\text { products/services }\end{array}$ & 5.79 & 1.32 & -1.30 & 1.84 \\
\hline 27 & characterised by high social prestige & 5.46 & 1.46 & -0.74 & 0.00 \\
\hline 28 & $\begin{array}{l}\text { gives you a sense of pride in your } \\
\text { duties }\end{array}$ & 6.28 & 1.02 & -1.44 & 1.73 \\
\hline 29 & $\begin{array}{l}\text { working at a company that supports } \\
\text { the local community }\end{array}$ & 4.65 & 1.64 & -0.40 & -0.37 \\
\hline
\end{tabular}

Source: own study.

According to the respondents, regardless of gender, an ideal job should be in line with their interests (6.40) as well as guarantee job stability (6.38) and high pay (6.37). Additionally, the workplace should have a friendly atmosphere (6.33), and the job itself should provide one with respect among clients and colleagues alike (6.28) as well as provide a sense of pride in one's duties (6.28). On the other hand, the least favourable features of a dream job indicated by respondents included irregular working hours, requiring mobility, and having to tackle a large number of duties to be performed rapidly.

The Mann-Whitney U test and the Wald-Wolfowitz runs test were also used while analysing this issue, i.e., the characteristics of an ideal job from the gender perspective.

The results of the Mann-Whitney $U$ test indicated a statistically significant variation in median values $(p<0.05)$ in the case of traits such as allows you to decide for yourself how to perform your duties (5), involves irregular working hours (7), requires mobility (8), enables you to influence decisions vital to the company (15), and enables you to improve your skills (17). This means that while graduates are aware of the requirements of today's job market, they still have certain expectations related to the ideal job (e.g., if the job requires mobility, they wish to be able to independently decide how to perform their assigned duties). Similar to their peers in other countries, the respondents want to have a say in decisions that are important for both improving their skills and the development of the business itself.

The Wald-Wolfowitz runs test also showed significant variation in the mean value of 21 traits $(p<0.05)$. Only in the case of eight traits (work matching your interests (1), allows you to make full use of all your skills and knowledge (3), involves a high volume and rapid pace of work (6), involves working in an attractive location (10), enables you to influence decisions vital to the company (15), makes you feel supported by colleagues (23), provides a sense of belonging and integration with the team (25), characterized by high social prestige (27)) was the influence of gender not confirmed. As a workplace characteristics evaluation determinant, gender was found to be important for such characteristics as ease of commuting (9), wage conditions (14), skill improvement opportunities (17), development both inside and outside the workplace (18), and the relation between the company's activities and the local environment (29). It was these qualities that the female respondents emphasised by giving them rating values exceeding the mean.

Continuing the analysis of the way gender affects the perception of characteristics of an ideal job, the subsequent part of the research included aggregating the characteristics analysed into five variables (using the arithmetic mean of the characteristics making up the variables, which are presented in Table 1). Based on the results obtained, it can be concluded that students-regardless of gender-considered social relationships (score of 6.12) and economic benefits (6.10) to be the most vital features of an ideal job, whereas the job contents was rated the lowest (5.18) (Figure 2). 


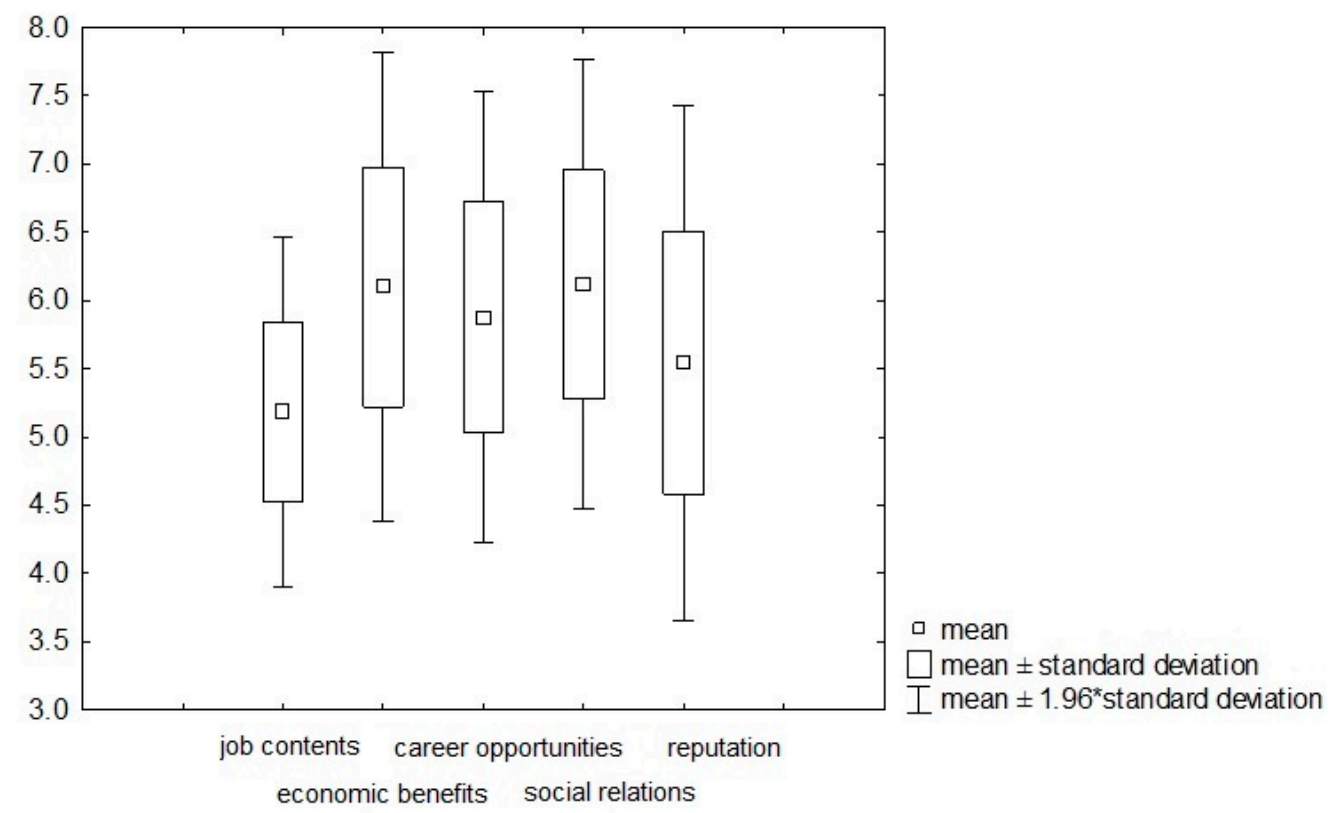

Figure 2. The respondents' expectations concerning an ideal workplace. Source: own research.

In-depth statistical analyses further revealed that the study populations have a different median $(p=0.002)$ in the case of the "job contents" variable. On the other hand, the Wald-Wolfowitz test showed that there exists a statistically significant variation in the mean values of all variables examined, except for the job contents variable $(p<0.001)$. Considering the number of runs and the number of tied ranks, it should be noted that the greatest variation in mean scores was found in the case of the "career opportunities" and "social relations" variables, with both being rated significantly higher by women than by men. These results confirm that self-development opportunities and building good social relations at the workplace are vital aspects of work for women. For men, economic benefits and workplace reputation seem to be more important in this regard.

\subsection{The Attractiveness of Agribusiness Jobs from A Gender Perspective}

The survey further analysed the respondents' opinions on the attractiveness of working in agribusiness (Figure 3). The results of the analyses indicate that, from the respondents' point of view, working in agribusiness--both in the short and long term-can be an interesting career stage. Moreover, it turned out that working as a sales representative is not an attractive prospect for the respondents (despite high market demand for employees of this profession). This is true for both men and women (statistical analysis showed significant variation in scores awarded, both in terms of the mean and the median value in the case of all aspects discussed). 


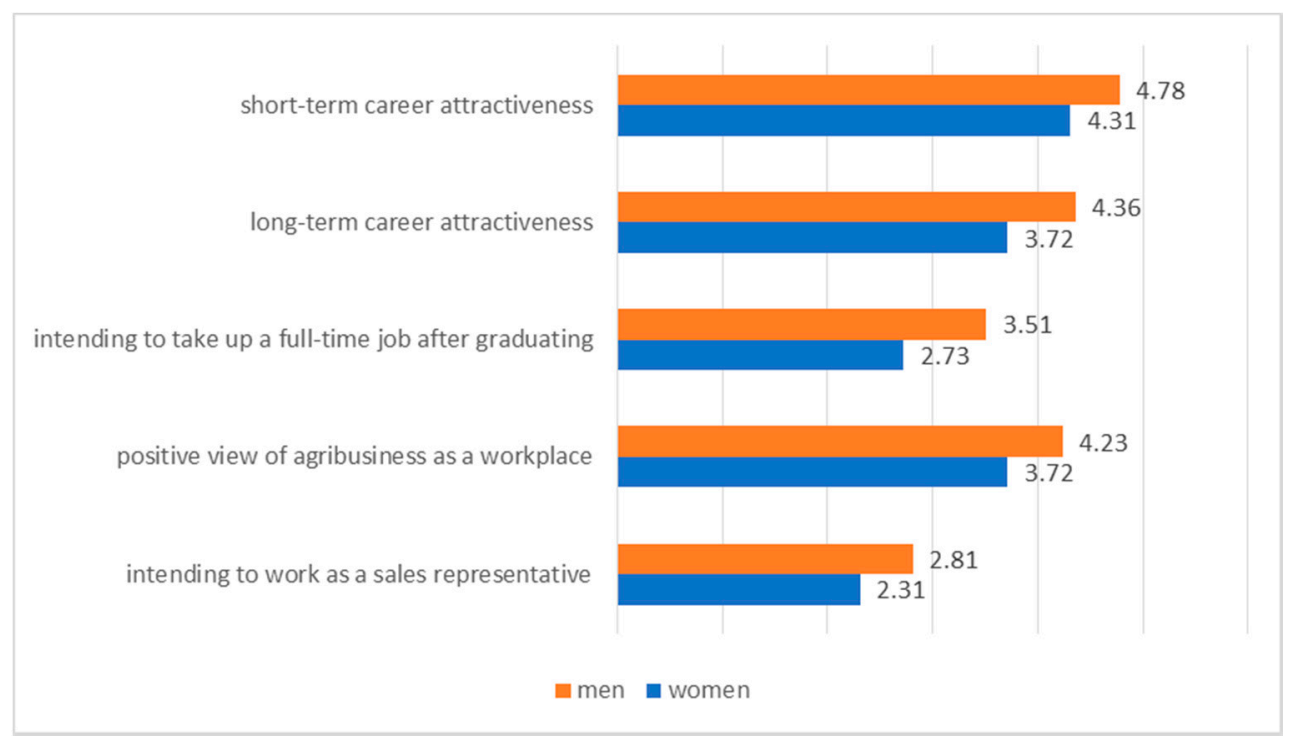

Figure 3. Perceiving agribusiness as a career destination. Source: own research.

Such a perception of agribusiness was significantly affected by the work experience gained by the survey participants during their education (especially as part of the university internships and apprenticeships, but also their own activities in this regard). This characteristic was also subjected to in-depth statistical analysis to determine the impact of experience (stage one) and gender (stage two) on the people's image of an ideal job.

The first stage involved performing a Mann-Whitney $U$ test, which showed that experience has a significant impact $(p<0.05)$ only in the case of three features, i.e., irregular working hours (7), social benefits received (12) and working alongside competent colleagues (24). A Wald-Wolfowitz runs test was also performed, and in this case, experience turned out to be significant for the evaluation of five features of an ideal job, i.e., high task variability (4), irregular working hours (7), skill improvement opportunities (17), combining private and professional life in a relatively seamless way (20) and a sense of pride in one's work (28).

The second stage of the analysis showed that, in the case of women, work experience had a statistically significant $(p<0.05)$ impact on such characteristics of an ideal job as involves irregular working hours (7), requires mobility (8), social benefits received (12) and working alongside competent colleagues (24) (Mann-Whitney U test). In the case of the Wald-Wolfowitz runs test, these also included such characteristics as ease of commuting (9), clear career path (16), enabling long-term career development (18), feeling the support of one's co-workers (23) and a sense of pride in one's work (28), in addition to the previously indicated characteristics of involves irregular working hours (7) and requires mobility (8).

A similar analysis of the data from the male study group indicated that experience affects the evaluation of only three variables, i.e., the ability to decide for yourself how to perform your duties (5), involves irregular working hours (7) (Mann-Whitney $U$ test) and combining private and professional life in a relatively seamless way (20) (Wald-Wolfowitz runs test). The tests showed statistically significant variation in the scores given to the ideal job characteristics studied.

\subsection{Professional Experience and Plans to Start A Business}

The analysis of the collected research material related to work experience evaluation and plans for starting a proprietary business after graduation allowed us to determine that the respondents are active people who strive to accumulate work experience (the vast majority of respondents $(60.6 \%)$ reported having at least one month of professional experience). The mean work experience length was 16 months, while the median was 9 months. At the same time, despite the predominance of women among the study participants, 
as noted earlier, there was no statistically significant variation in the impact of gender on the length of work experience (Table 3).

Table 3. Professional experience and plans to start a business.

\begin{tabular}{|c|c|c|}
\hline Description & $\begin{array}{l}\text { Women } \\
(n=395)\end{array}$ & $\begin{array}{c}\text { Men } \\
(n=90)\end{array}$ \\
\hline $\begin{array}{c}\text { Professional experience } \\
\text { yes } \\
\text { no }\end{array}$ & $\begin{array}{l}61.0 \% \\
39.0 \%\end{array}$ & $\begin{array}{l}58.9 \% \\
41.1 \%\end{array}$ \\
\hline \multicolumn{3}{|c|}{$\chi^{2}=0.14 p>0.05$} \\
\hline $\begin{array}{l}\text { Plans to start a business after graduation } \\
\text { yes } \\
\text { no }\end{array}$ & $\begin{array}{l}25.6 \% \\
74.4 \%\end{array}$ & $\begin{array}{l}42.2 \% \\
57.8 \%\end{array}$ \\
\hline \multicolumn{3}{|c|}{$\chi^{2}=9.94 p=0.002$} \\
\hline
\end{tabular}

Source: own research.

However, it is different when it comes to plans to start a business. The effect of the respondents' gender on this decision was found to be a statistically significant variable. The results indicated that men had higher aspirations in striving to start their own business. One can assume that this result may be due to women's desire to obtain higher education, a tendency which has been visible for years, and in the case of the female students surveyed, their desire to undertake post-graduate studies, i.e., to obtain their Master's degree and finish their full education cycle. This observation is confirmed both by the significant degree of feminisation of Master's degree courses at agricultural, vocational and technical and agricultural universities as well as studies published by other authors [44-46].

\subsection{The Attractiveness of Working in Agribusiness from the Perspective of Starting A Business}

Preparing graduates not only for employment but also starting their own business is a vital element in the process of educating human resources to support the economy. According to the survey, almost one third of the respondents (28.7\%) plan to start a business immediately after graduation.

Therefore, the final stage of the study involved an attempt to determine the impact that the intention to start one's own business has on the way the respondents perceive the characteristics of an ideal job, irrespective of gender. The Mann-Whitney U test showed that the intention to become self-employed influenced the evaluation of as many as nine characteristics, i.e., work matching one's interests (1), high task variability (4), ability to decide on how to perform one's duties (5), irregular working hours (7), mobility requirements (8), having a say in decisions vital for the company (15), work related to offering high-quality products/services (26), job providing high social prestige (27) and sense of pride in the work performed (28) (these characteristics were statistically significant $(p<0.05)$ and were characterised by variation in median values). At the same time, when analysing the traits studied in terms of the average value, it was determined that they differed significantly only in the case of trait (15), i.e., having a say in decisions vital for the company.

To conclude the study, the respondents' answers on looking for a job outside agribusiness-despite having received an education that by definition enables them to work in this sector-were analysed as well. The results obtained indicated that the respondents believed that they were well prepared for jobs outside the food sector as well (the vast majority of their answers were positive (4.75). However, in the case of women (the mean value was 4.73), this belief was weaker than in the case of men (4.84), which was also confirmed by the statistical analysis results showing a statistically significant impact of gender on this issue $(p=0.001)$. 


\section{Discussion}

While numerous authors have pointed to gender issues as a factor influencing university graduate preferences related to both career choices and expectations regarding future work [47-49], these issues have rarely been analysed in relation to agribusiness and agriculture, especially in the case of the European literature. On the other hand, numerous agribusiness-focused works concerning this area were published in countries that may be considered developing ones, such as Nigeria [50], Ethiopia [51], Indonesia [52] and many others [53]. Such studies were also conducted in the United States [54] and Canada [55]. Therefore, the research we present fills an important gap in the European literature concerning this area.

The research conducted indicates that, as a sector offering diverse jobs, agribusiness is an attractive career stage for all graduates surveyed. They perceive jobs in this sector as close to ideal (which supports the adopted H1 hypothesis, that both men and women perceive working in agribusiness as something close to an ideal job). The desired aspects of working in agribusiness rated highly by the respondents included work matching their interests, guaranteed employment stability, and high remuneration (depending on the subsector selected). They also pointed to a friendly workplace atmosphere, a chance to gain the respect of both clients and co-workers, and a sense of pride in one's duties. The least favourable characteristics identified included irregular working hours, required mobility and a large number of varied tasks to be performed at a rapid pace. The results analysed were linked to the fact that the respondents belong to the so-called labour market Generation Z, which both partly confirms the adopted hypothesis (H4; i.e., since the examined group of graduates belongs to the so-called Generation $Z$, this affects what they perceive as an ideal job) and is in line with the research of other authors [56]. The students participating in the study were aged 21 and 23 , which, according to the generally accepted typology, makes it possible to classify them as Generation Z (i.e., people born in 1991-2000). Apart from a number of characteristics of this generation described in the literature [57], Generation $\mathrm{Z}$ employees are characterised by a realistic approach to life. Our study shows that this approach may have different dimensions in relation to gender, i.e., men tend to change jobs frequently and seek to maximise their earnings, while women seek stability and social inclusion. This is also confirmed by the studies of other authors [57-59]. On the one hand, representatives of this generation are characterised by confidence, openness and creativity, while on the other, they would also like to quickly attain professional success and rapidly build their careers. They assume that if the given job is not satisfactory for them and does not enable rapid development, they will simply change it for another one [60]; due to its complexity and the diverse range of jobs available, the agribusiness sector offers them such opportunities [4]. Rapid transitions between different employers are related to the low to moderate employer loyalty that is typical for Generation $\mathrm{Z}$ employees, not their refusal to accept a workplace hierarchy [61]. Our findings support this fact as well. Our analysis indicates that, from the respondents' point of view, working in agribusiness can be an interesting career stage, both in the short and long term, yet at the same time, the respondents are convinced that they can easily find a job outside agribusiness.

From a gender perspective, men and women view working in agribusiness differently. The results confirmed that career opportunities combined with building good social relationships at the workplace are vital for women, whereas economic benefits and the reputation of the workplace itself are more important for men (supporting the $\mathrm{H} 2 \mathrm{hy}-$ pothesis, i.e., women's expectations concerning the demands of this type of work and its environmental impact are higher than men's). While men had higher aspirations to set up a business (which confirms the H3 hypothesis, i.e., women are less likely than men to decide to set up their own business), women postponed doing so, which—as indicated by our observations-is related to their aspirations to obtain a university education, and in the case of the female students surveyed, to undertake a post-graduate course to obtain a Master's degree and complete their full education cycle. From the point of view of the increasing feminisation of all fields of study, which is noticeable not only at Polish 
universities but also in many other countries, including China [62], India [63], Syria [64] and across Europe [65], this may bode well for raising the level of knowledge and skills, which is necessary for the continued development of agriculture and agribusiness alike.

\section{Conclusions}

Based on the conducted research, the following conclusions can be drawn:

1. In the opinion of the surveyed students (men and women), working conditions in agribusiness are close to those expected and accepted by them. Work in this sector is also an interesting space for both gainful employment and running one's own business.

2. Men are distinguished by their tendency to start their careers earlier and to strive for professional success; economic satisfaction and the reputation of the workplace are more important than loyalty to the employer.

3. Women prefer the possibility of self-development through full higher education (Bachelor's and Master's degrees). Moreover, they are characterised by later entry into the labour market, the expectation of good social relations in the place of employment, stronger loyalty to the employer and greater sensitivity to environmental protection problems.

4. The stated preferences of the surveyed students (men and women) are a good prognosis for meeting the needs of agribusiness in terms of knowledge and competences of employees.

The presented results are certainly not exhaustive, but they can be a useful source of knowledge about the expectations of young people in the labour market, both for managers working in agribusiness companies and for those involved in recruitment for this sector. They may also be useful for managers of companies from other industries. We hope that they will encourage further research into the labour market, dominated by Generation $\mathrm{Z}$ in other sectors.

To conclude, we would like to note that our research is causal and needs to be continued in other countries.

Supplementary Materials: The following are available online at https: / /www.mdpi.com/2077-047 2/11/3/202/s1, Survey questionnaire.

Author Contributions: Conceptualization, M.K.-K. and J.U.; methodology, M.K.-K. and J.U.; software, J.U.; formal analysis, J.U.; investigation, M.K.-K. and J.U.; data curation, J.U.; writing—original draft preparation, M.K.-K. and J.U.; writing-review and editing, M.K.-K. and J.U.; visualization, J.U.; supervision, M.K.-K.; funding acquisition, M.K.-K. All authors have read and agreed to the published version of the manuscript.

Funding: This research received no external funding.

Institutional Review Board Statement: Not applicable.

Informed Consent Statement: Not applicable.

Data Availability Statement: The data that support the findings of this study are available upon request from the authors.

Conflicts of Interest: The authors declare no conflict of interest.

\section{References}

1. Van Fleet, D.D.; Van Fleet, E.W.; Seperich, G.J. Agribusiness: Principles of Management; Delmar/Cengage Learning: Clifton Park, NY, USA, 2014.

2. King, R.P.; Boehlje, M.; Cook, M.L.; Sonka, S.T. Agribusiness economics and management. Am. J. Agric. Econ. 2010, 92, 554-570. [CrossRef]

3. Bear-Nawrocka, A. The role of agriculture in the national economy of EU countries. J. Agribus. Rural Dev. 2016, 4, 501-510. [CrossRef]

4. Kozera-Kowalska, M.; Uglis, J. Postrzeganie kariery zawodowej w agrobiznesie przez studentów Uniwersytetu Przyrodniczego w Poznaniu-studium przypadku (Perception of professional career in agribusiness by students from the Poznań University of Life Sciences-case study). Rocz. Nauk. Stowarzyszenia Ekon. Rol. I Agrobiz. 2017, 19, 143-149. 
5. The Future of Food and Farming-for a Flexible, Fair and Sustainable Common Agricultural Policy. Available online: https: / / ec.europa.eu/commission/presscorner/detail/en/IP_17_4841 (accessed on 1 February 2021).

6. Kozera, M. Wiedzochłonność Produkcji Rolniczej Jako Wyzwanie Dla Kształcenia Zawodowego W Polsce (The knowledgeIntensive of Agricultural Production as the Challenge for the Agricultural Education System in Poland). Rocz. Nauk. Stowarzyszenia Ekon. Rol. I Agrobiz. 2014, 16, 268-273.

7. Kozera-Kowalska, M.; Kalinowski, S. Wiedzochłonność obszarów wiejskich w warunkach zrównoważonego rozwoju. Handel Wewnętrzny 2016, 4, 88-100.

8. Matras-Bolibok, A.; Kis, K. European innovation partnership as a framework for open innovation in agriculture. Rocz. Nauk. Stowarzyszenia Ekon. Rol. I Agrobiz. 2014, 16, 339-343.

9. Frick, M.J.; Birkenholz, R.J.; Gardner, H.; Machtmes, K. Rural and urban inner-city high school student knowledge and perception of agriculture. J. Agric. Educ. 1995, 36, 1-9. [CrossRef]

10. Unay-Gailhard, İ.; Bavorová, M.; Bednaříková, Z.; Ponkina, E.V. “I Don’t Want to Work in Agriculture!” The Transition from Agricultural Education to the Labor Market in Rural Russia. Rural Sociol. 2019, 84, 315-349. [CrossRef]

11. Akareem, H.S.; Hossain, S.S. Determinants of education quality: What makes students' perception different? Open Rev. Educ. Res. 2016, 3, 52-67. [CrossRef]

12. Dolot, A. Job search by the young generation-selected problems-in light of empirical research. Studia Ekon. Zesz. Nauk. Ekon. W Katowicach 2018, 359, 284-299.

13. Okoń-Horodyńska, E.; Zachorowska-Mazurkiewicz, A.; Wisła, R.; Sierotowicz, T. Gender, innovative capacity, and the process of innovation: A case of Poland. Econ. Sociol. 2016, 9, 252-263. [CrossRef]

14. Włodarczyk, K.; Sikorska, J. Aspiracje zawodowe młodych osób na polskim rynku pracy (Career aspirations of young people on the polish labour market). Studia Ekon. Zesz. Nauk. Ekon. W Katowicach 2017, 310, 201-214.

15. Uglis, J.; Kozera-Kowalska, M. Students' Perception of Ideal Work-An Agribusiness Sector Case Study. In Double-blind peer reviewed proceedings part II of the International Scientific Conference Hradec Economic Days 2019; Králové, H., Jedlička, P., Marešová, P., Soukal, I., Králové, H.C., Eds.; University of Hradec Kralove: Hradec Králové, Czechia, 2019; pp. 485-493. [CrossRef]

16. Bzowska-Bakalarz, M.; Pieczykolan, E. Jakość kształcenia w ocenie absolwentów wydziału techniki rolniczej. Inżynieria Rol. 2005, 9, 65-74.

17. Dziedziczak-Foltyn, A. Równość płci w szkolnictwie wyższym i nauce-teoria i praktyka. Przeglad Socjol. 2010, 59, 87-107.

18. Jelonek, M.; Szklarczyk, D. Kogo kształca polskie szkoty. Analiza Kierunków Kształcenia w Szkołach Ponadgimnazjalnych i Wyższych; Polska Agencja Rozwoju Przedsiębiorczości: Warszawa, Poland, 2012.

19. Liu, J.C.; Xu, Z.G.; Zheng, Q.F.; Hua, L. Is the feminization of labor harmful to agricultural production? The decision-making and production control perspective. J. Integr. Agric. 2019, 18, 1392-1401. [CrossRef]

20. Szkolnictwo wyższe w Roku Akademickim 2018/2019. GUS: Warszawa, Poland. Available online: https://stat.gov.pl/obszarytematyczne/edukacja/edukacja/szkolnictwo-wyzsze-w-roku-akademickim-20182019-wyniki-wstepne,8,6.html (accessed on 22 February 2021).

21. Marcysiak, T.; Prus, P. Life strategies of rural inhabitants of unfixed economic function. In Proceedings of the 26th International Scientific Conference Agrarian Perspectives XXVI "Competitiveness of European Agriculture and Food Sectors", Prague, Czechia, 13-15 September 2017; pp. 212-218.

22. Kaminski, R.; Marcysiak, T.; Prus, P. The Development of Green Care in Poland. In Proceedings of the 2018 International Conference “Economic Science for Rural Development", No 49, Jelgava, LLU ESAF, Jelgava, Latvia, 9-11 May 2018; pp. 307-315, ISSN 1691-3078, ISSN 2255-9930, on line ISBN 978-9984-48-294-1, (E-book). [CrossRef]

23. Uglis, J.; Kozera-Kowalska, M. Synthetic measure of rural area attractiveness for living, working and business activities-Concept analysis and statistical evaluation. Ann. Pol. Assoc. Agric. Agribus. Econ. 2019, 21, 275-284. [CrossRef]

24. Mrówczyńska-Kamińska, A.; Bajan, B. Importance and share of agribusiness in the Chinese economy (2000-2014). Heliyon 2019, 5, e02884. [CrossRef]

25. Davis, J.H.; Goldberg, R.A. A Concept of Agribusiness, Boston: Division of Research, Graduate School of Business Administration; Harvard University: Cambridge, MA, USA, 1957.

26. White, B. Agriculture and the generation problem: Rural youth, employment and the future of farming. IDS Bull. 2012, 43, 9-19. [CrossRef]

27. Roser, M. Employment in Agriculture. Our World in Data. Available online: https://ourworldindata.org/employment-inagriculture?source=post_page (accessed on 28 January 2021).

28. Kolodziejczak, W. Zatrudnienie i wartość dodana brutto w sektorach gospodarki państw Unii Europejskiej w latach 2002 i 2016. Probl. Rol. Światowego 2018, 18, 270-283. [CrossRef]

29. Lewandowski, P.; Magda, I. (Eds.) Zatrudnienie w Polsce 2013. In Praca W Dobie Przemian Strukturalnych; Warszawa: Centrum Rozwoju Zasobów Ludzkich, Poland, 2014; Available online: http://wise-europa.eu/wp-content/uploads/2016/03/ Zatrudnienie-w-Polsce-2013.pdf (accessed on 28 January 2021).

30. Uglis, J.; Kozera-Kowalska, M.; Łopuszyńska, Z. Staff education system for agribusiness-cases study Poznań University of Life Sciences, Poland. In Proceedings of International Scientific Days; Horská, E., Kapsdorferová, Z., Hallová, M., Eds.; Wolters Kluwer ČR: Prague, Czech Republic; Nitra, Slovak Republic, 2018; pp. 2072-2082. 
31. Agricultural Labour Productivity Down by 4\% in 2020, Products Eurostat News 16/12/2020. Available online: https:/ / ec.europa. eu/eurostat/web/products-eurostat-news/- /ddn-20201216-1 (accessed on 25 January 2021).

32. Kozera, M. Jakość zasobów ludzkich na obszarach wiejskich (Quality of human resources in rural areas). Probl. Rol. Światowego 2011, 11, 109-117.

33. Kozera, M. Changes in Human Resources in Polish Agriculture. J. Agric. Sci. Technol. A 2012, 2, 937. Available online: http:/ / www.davidpublisher.org/Article/index?id=14830.html (accessed on 25 January 2021).

34. Koloskova, Y.; Dalisova, N.; Shaporova, Z. The role of human capital in the development of agribusiness. In IOP Conference Series: Earth and Environmental Science; IOP Publishing: Bristol, UK, 2019; Volume 315.

35. Wilson, R.A.; Briscoe, G. The impact of human capital on economic growth: A review. In Impact of Education and Training. Third Report on Vocational Training Research in Europe: Background Report; Cedefop References series, 3036; EUR-OP: Luxembourg, 2004; pp. 9-70.

36. Baptista, R.D. Technological transition and the new skills required by the agribusiness sector. Int. Food Agribus. Manag. Rev. 2012, 15, 105-109.

37. Oldrup, H. Woman and agriculture-Lessons from agriculture? In Forestry Serving Urbanised Societies. IUFRO World Ser. 2004, 14, 377-384.

38. Pini, B. The third sex: Women leaders in Australian agriculture. Gend. Work Organ. 2005, 12, 73-88. [CrossRef]

39. Sachs, C. Gendered Fields: Rural Women, Agriculture, and Environment; Westview Press Inc: Boulder, CO, USA, 1996.

40. Chanana-Nag, N.; Aggarwal, P.K. Woman in agriculture, and climate risks: Hotspots for development. Clim. Chang. 2020, 158, 13-27. [CrossRef]

41. Pravalikka, M.; Vignaneswari, B.; Rajamatha, Y. The Role of Woman in Agriculture Sector in Rural Areas-A Study. IJRAR 2018, 5, 47-50.

42. Parlińska, M.; Jaśkiewicz, J.; Rackiewicz, I. Wyzwania dla rolnictwa związane ze strategia Europejski Zielony Ład w okresie pandemii. Probl. World Agric. Probl. Rol. Światowego 2020, 20, 22-36.

43. Bednarska, M. Kariera zawodowa w hotelarstwie w opinii studentów-Implikacje dla współpracy praktyki gospodarczej z systemem edukacji (Students' attitudes towards a career in the hospitality industry-Implications for cooperation between the hospitality sector and educational institutions). Studia Oeconomica Posnaniensia 2014, 2, 152-167.

44. Caraway, T.L. The political economy of feminization: From" cheap labor" to gendered discourses of work. Politics Gend. 2005, 1, 399. [CrossRef]

45. Leathwood, C.; Read, B. Gender and the Changing Face of Higher Education: A Feminized Future? McGraw-Hill Education: London, UK, 2008.

46. Kabalski, P.; Szwajcar, J. Feminizacja studiów w zakresie rachunkowości w Polsce-przyczyny i skutki. Zesz. Teor. Rachun. 2015, 81, 85-106. [CrossRef]

47. Toro-Morn, M.; Sprecher, S. A cross-cultural comparison of mate preferences among university students; the United States Vs. the People's Republic of China (PRC). J. Comp. Fam. Stud. 2003, 34, 151-170. [CrossRef]

48. Reda, G.; Hamdan, A. Gender, language, and society: Saudi female university students' perception of the category of professions. Géneros 2015, 4, 666-689. [CrossRef]

49. Reissova, A.; Šimsová, J.; Laslofi, J. Preferences of current female university students-family or career? J. Interdiscip. Res. 2018, 8, 202-206.

50. Etowa, E.B.; Idu, M.A.; Nweze, N.J. A gender comparison of the socioeconomic factors determining credit demand by agrirepreneurs in cross river state, Nigeria. Int. J. Agric. Econ. Ext. 2009, 1, 1-8.

51. Moreda, T. Review on Factors Affecting Youth Participation in Agribusiness in Ethiopia. Plant 2020, 8, 80. [CrossRef]

52. Patrick, I. Contract farming in Indonesia: Smallholders and Agribusiness Working Together; ACIAR Technical Reports No. 54; Australian Centre for International Agricultural Research: Canberra, Australia, 2004; Volume 88. [CrossRef]

53. Huyer, S. Closing the Gender Gap in Agriculture. Available online: https://journals.sagepub.com/doi/pdf/10.1177/0971852416 643872 (accessed on 29 January 2021).

54. Qenani-Petrela, E.; Wolf, M.M. Differential Earnings of the Agricultural Graduates: New Evidence from the Agribusiness Industry. Int. Food Agribus. Manag. Rev. 2007, 10, 49-66.

55. Reed, M.G. Marginality and gender at work in forestry communities of British Columbia, Canada. J. Rural Stud. 2003, 19, 373-389. [CrossRef]

56. Ozkan, M.; Solmaz, B. The changing face of the employees-generation Z and their perceptions of work (a study applied to university students). Procedia Econ. Financ. 2015, 26, 476-483. [CrossRef]

57. Żarczyńska-Dobiesz, A.; Chomątowska, B. Pokolenie" Z" na rynku pracy-wyzwania dla zarządzania zasobami ludzkimi. Pr. Nauk. Uniw. Ekon. We Wroctawiu 2014, 350, 405-415. [CrossRef]

58. Okoń-Horodyńska, E.; Zachorowska-Mazurkiewicz, A.; Wisła, R.; Sierotowicz, T. Gender in the Creation of Intellectual Property of the Selected European Union Countries. Econ. Sociol. 2015, 8, 11-25.

59. Lipińska-Grobelny, A.; Ciesielska, O. Zaangażowanie w pracę i przywiązanie do organizacji-Analiza międzypokoleniowa i międzypłciowa. Hum. Resour. Manag. Zarz. Zasobami Ludzkimi 2018, 3-4, 129-144.

60. Paszkiewicz, A. Młode Pokolenie na Rynku Pracy. Jak Zrozumieć Pokolenie Y i Wchodzace na Rynek Pokolenie Z. Available online: https:/ / mondi-polska.pl/blog/pokolenie_y/ (accessed on 29 January 2021). 
61. Lazányi, K.; Bilan, Y. Generetion Z on the labour market: Do they trust others within their workplace? Polish J. Manag. Stud. 2017, 16, 78-93. [CrossRef]

62. Meng, X. Feminization of Agricultural Production in Rural China: A Sociological Analysis. Ph.D. Thesis, Wageningen University, Wageningen, The Netherlands, 2014.

63. Garikipati, S. Feminization of Agricultural Labor and Women's Domestic Status: Evidence from Labor Households in India Work. Pap. 2006, 1-20. [CrossRef]

64. Abdelali-Martini, M.; Goldey, P.; Jones, G.; Bailey, E. Towards a feminization of agricultural labour in northwest Syria. J. Peasant Stud. 2003, 30, 71-94. [CrossRef]

65. Slavchevska, V.; Kaaria, S.; Taivalmaa, S.L. The Feminization of Agriculture. In The Oxford Handbook of Food, Water and Society; Oxford University Press: Oxford, UK, 2019. [CrossRef] 